\title{
Desensitization to Parathyroid Hormone in Renal Cells from Aged Rats Is Associated with Alterations in G-Protein Activity
}

\author{
Hiroyuki Hanai, C. Tony Liang, Linda Cheng, and Bertram Sacktor ${ }^{\dagger}$ \\ Laboratory of Biological Chemistry, National Institute on Aging, National Institutes of Health, Gerontology Research Center, \\ Baltimore, Maryland 21224
}

\begin{abstract}
Parathyroid hormone (PTH)-stimulated $\mathrm{Na}^{+} / \mathrm{Ca}^{2+}$ exchange activity, but not forskolin-sensitive $\mathrm{Na}^{+}$-dependent $\mathrm{Ca}^{2+}$ efflux, was blunted in renal cortical cells from aged rats. PTH-sensitive adenylate cyclase activity in renal membranes from senescent rats also declined, but forskolin-stimulated activity did not change. In addition, cholera toxin- and pertussis toxin-stimulated $\mathrm{Na}^{+}$-dependent $\mathrm{Ca}^{2+}$ efflux and cAMP formation were blunted in cells from aged animals. Further, cells from aged rats had decreased $G_{s}-\alpha$ and $G_{i}-\alpha$ proteins, as detected by ADP-ribosylation. These findings would be consistent with the proposal of an age-associated heterologous desensitization that involved the G-proteins. Serum concentrations of iPTH were increased in the old rat, suggesting that the desensitization to PTH in the aging rat represented an adaptive response to prolonged stimulation by the hormone. This hypothesis was supported by the findings that the attenuated PTH-sensitive $\mathrm{Na}^{+}$/ $\mathrm{Ca}^{2+}$ exchange activity, cAMP formation, and adenylate cyclase activity in cells from old rats could be reversed by parathyroidectomy. The decreased label in cholera toxin-catalyzed ADP-ribosylated $G_{s}-\alpha$ and pertussis toxin catalyzed ADP-ribosylated $G_{i}-\alpha$ found in cells from aged rats was also largely negated by the surgery. In conclusion, the results suggest that the age-related blunting in the responses of renal cells to PTH was associated with a deficit in G-protein function and that this alteration could be reversed by removal of the parathyroid gland.
\end{abstract}

\section{Introduction}

Although PTH has long been known to stimulate renal $\mathrm{Ca}^{2+}$ reabsorption $(1,2)$, the biochemical mechanism by which the hormone increases $\mathrm{Ca}^{2+}$ transport is largely unknown. PTH receptors have been localized to the basolateral membrane of the tubular cell, and reception is coupled to adenylate cyclase and phospholipase $\mathrm{C}$ activation (2-4). The basolateral membrane also possesses $\mathrm{Na}^{+} / \mathrm{Ca}^{2+}$ exchange activity (5-8). Membrane vesicles prepared from parathyroidectomized animals have decreased exchange activity, and this activity is restored when synthetic bPTH $(1-34)$ is infused into the parathyroidectomized animal $(6,8)$. More recently, we have reported on the presence of $\mathrm{a} \mathrm{Na}^{+} / \mathrm{Ca}^{2+}$ exchange carrier in cells isolated from

$\dagger$ Deceased.

Address reprint requests to Dr. C. Tony Liang, Laboratory of Biological Chemistry, National Institute on Aging, National Institutes of Health, Gerontology Research Center, Baltimore, MD 21224.

Received for publication 22 June 1988 and in revised form $17 \mathrm{Au}$ gust 1988.

The Journal of Clinical Investigation, Inc.

Volume 83, January 1989, 268-277 the rat renal cortex and have shown that PTH, when incubated with the cells in vitro, increases $\mathrm{Na}^{+}$-dependent $\mathrm{Ca}^{2+}$ efflux $\sim 60 \%$ (9). The effect of the hormone is specific for biologically active PTH analogues and can be mimicked by cAMP and forskolin (9). These findings, as well as others (9), are consistent with the view that in the rat cAMP acts as the intracellular messenger to increase $\mathrm{Na}^{+} / \mathrm{Ca}^{2+}$ exchange activity. However, an alternate pathway to regulate $\mathrm{Na}^{+} / \mathrm{Ca}^{2+}$ exchange activity by PTH has been reported to be independent of cAMP (4).

In addition, we have found that PTH-sensitive $\mathrm{Na}^{+} / \mathrm{Ca}^{2+}$ exchange activity is blunted in cells from senescent $(24 \mathrm{mo})$ rats (9). Basal $\mathrm{Na}^{+}$-dependent $\mathrm{Ca}^{2+}$ efflux and $\mathrm{Na}^{+}$-independent $\mathrm{Ca}^{2+}$ efflux are not altered in the aged animal. PTH-stimulated adenylate cyclase is also decreased in aging (9). The aged rat has increased levels of immunoreactive PTH (iPTH) (10-13). Moreover, when cultured renal cells are exposed to PTH they become refractory in their cAMP response to a subsequent incubation with the hormone (14-16). In contrast, the actions of forskolin are not diminished in the senescent animal (9). Thus, these findings are compatible with a mechanism of desensitization to PTH that occurred at the level of the receptor or hormone-receptor coupling to adenylate cyclase, and we have suggested that additional studies on the PTH receptor and the GTP-binding proteins with respect to age are indicated (9).

Agonist stimulation and inhibition of cAMP production are known to involve G-proteins that couple receptors to the catalytic unit. Cells possess distinct G-proteins that are associated with stimulation $\left(G_{s}\right)^{1}$ and inhibition $\left(G_{i}\right)$ of adenylate cyclase (17). $G_{s}$ and $G_{i}$ are oligomeric proteins with distinct $\alpha$ subunits that may be radiolabeled with cholera and pertussis toxin, respectively (17). ADP-ribosylation of $\mathrm{G}_{\mathrm{s}}$ by cholera toxin activates $G_{s}$, whereas ADP-ribosylation of $G_{i}$ by pertussis toxin inactivates $G_{i}(17-19)$. We have used the two toxins as probes to examine whether the two G-proteins are involved in PTH desensitization in the aging rat model. The evidence reported in this paper suggests that loss of G-protein activity is associated with desensitization to PTH in renal cells of aged rats.

\section{Methods}

Animals and isolation of renal cells. Wistar-derived male rats were obtained from the Animal Facility, Gerontology Research Center, National Institute on Aging. Animals of two ages were used: the 6-moold rat, representing a sexually mature young adult beyond the stage of rapid linear growth; and the 24-mo-old rat, representing the senescent animal. In our colony, the mean $50 \%$ mortality is $\sim 24 \mathrm{mo}$. Rats were maintained ad lib. on standard National Institutes of Health rat chow,

1. Abbreviations used in this paper: $\mathrm{G}_{\mathrm{i}}, \mathrm{G}$ protein inhibition; $\mathrm{G}_{\mathrm{s}}, \mathrm{G}$ protein stimulation; PTX, parathyroidectomy. 
which consisted of $23.5 \%$ protein, $1.2 \% \mathrm{Ca}$, and $0.95 \% \mathrm{P}$. The photo period consisted of $12 \mathrm{~h}$ light and $12 \mathrm{~h}$ dark; room temperature was kept at $22-24^{\circ} \mathrm{C}$. In experiments in which the rats were parathyroidectomized, the animals were anesthetized with sodium pentobarbital $(5 \mathrm{mg} / 100 \mathrm{~g}$ body $\mathrm{wt})$. Parathyroid glands were removed surgically by electrocautery or the animals were subject to sham operations. Rats were used 48-72 $\mathrm{h}$ after surgery. Completeness of the removal of the glands was verified by the decreases in serum $\mathrm{Ca}$ concentration and iPTH as reported below. iPTH was determined by RIA.

Renal cortical cells from the two kidneys of each rat were isolated as described in detail previously (9). The cells were suspended at a concentration of $10-15 \mathrm{mg}$ of cell protein/ $\mathrm{ml}$ in a medium containing $140 \mathrm{mM} \mathrm{KCl}, 10 \mathrm{mM}$ Hepes-Tris buffer, $\mathrm{pH}$ 7.4, $10 \mathrm{mM}$ mannose, 0.5 $\mathrm{mM} \beta$-hydroxybutyrate and $2.5 \mathrm{mM}$ glutamine. There were no significant differences between the cells from the different aged rats in cellular integrity and general metabolism, as assessed and reported earlier (9).

Measurement of calcium efflux. $\mathrm{Na}^{+}$-dependent ${ }^{45} \mathrm{Ca}^{2+}$ efflux was measured as previously reported (9). Briefly, the cells in a 50- $\mu 1$ aliquot of a freshly prepared suspension were preloaded with $\mathrm{Ca}$ by adding to the suspension $50 \mu \mathrm{l}$ of the incubation medium containing $2 \mathrm{mM}$ $\mathrm{CaCl}_{2}$ labeled with $0.25 \mu \mathrm{Ci}$ of ${ }^{45} \mathrm{Ca}^{2+}$ and incubating the mixture with constant shaking for $30 \mathrm{~min}$ at $37^{\circ} \mathrm{C}$. After the preloading period, efflux of Ca was initiated by the addition of $900 \mu \mathrm{l}$ of efflux medium containing either $140 \mathrm{mM} \mathrm{NaCl}$ or choline chloride, plus $2 \mathrm{mM}$ EGTA and $10 \mathrm{mM}$ Hepes-Tris buffer, $\mathrm{pH}$ 7.4. After $5 \mathrm{~s}$, efflux was terminated by the addition of $3 \mathrm{ml}$ of ice-cold choline-containing efflux medium and the mixture rapidly filtered on $5-\mu \mathrm{m}$ Millipore filters (SMWP 02500) (20). The reaction tube and filter were washed three times, each time with $3 \mathrm{ml}$ of ice-cold stopping solution. The cells and filter were digested with $1 \mathrm{ml}$ of $0.1 \mathrm{~N} \mathrm{NaOH}$ for several hours, $10 \mathrm{ml}$ of scintillation fluid (Ready Solv. MP; Beckman Instruments, Inc., Fullerton, CA) was then added, and radioactivity counted. Zero time values ( $0 \%$ efflux) were estimated from reactions in which the ice-cold stopping solution was added before the efflux medium and the contents of the reaction tube immediately filtered. All incubations were carried out at least in triplicate. Each experiment was repeated a minimum of five times, each with different cell preparations. Values are reported as the mean \pm SE for the different experiments. When the effects of PTH or forskolin on ${ }^{45} \mathrm{Ca}^{2+}$ efflux were measured, the agonists or vehicle controls were incubated with the renal cells for $1.5 \mathrm{~min}$ before the initiation of efflux. The effect of PTH on efflux was maximal after a 1.0- to 1.5-min incubation (9). When the actions of cholera and pertussis toxins were determined, the toxin was preactivated in a solution of 20 $\mathrm{mM}$ DTT for $30 \mathrm{~min}$ and $40 \mathrm{mM}$ DTT for $60 \mathrm{~min}$, respectively. The activated toxin was added to the cell suspension at the end of the ${ }^{45} \mathrm{Ca}$ preloading period and incubated with the cells for an additional 25 min. Efflux was initiated as described above.

ADP-ribosylation of $G$-proteins. A 200- $\mu$ l suspension of cells (8-10 $\mathrm{mg}$ of protein $/ \mathrm{ml}$ ) in $5 \mathrm{mM}$ sodium phosphate, $\mathrm{pH} \mathrm{8.0,} \mathrm{containing} 100$ $\mu \mathrm{M}$ leupeptin, $200 \mu \mathrm{M}$ PMSF, $100 \mathrm{U} / \mathrm{ml}$ aprotinin, and $1 \mathrm{mM}$ EGTA, was homogenized and the mixture centrifuged at $27,000 \mathrm{~g}$ for $15 \mathrm{~min}$ at $4^{\circ} \mathrm{C}$. The pellet was resuspended in the phosphate buffer, without protease inhibitors, and recentrifuged. The resultant pellet was suspended in $100 \mu \mathrm{l}$ of $100 \mathrm{mM}$ potassium phosphate, $\mathrm{pH} 7.5$, containing $100 \mathrm{U} / \mathrm{ml}$ Trasylol, $20 \mathrm{mM}$ thymidine, $2 \mathrm{mM}$ ATP, $4 \mathrm{mM}$ GTP, 10 $\mathrm{mM} \mathrm{MgCl} 2,25 \mu \mathrm{M}\left[{ }^{32} \mathrm{P}\right] \mathrm{NAD}$, and activated toxin. The protein contents of the membrane preparations from 6- and 24-mo-old rats were determined and adjusted to the same concentration before ADP-ribosylation. The concentrations of cholera toxin and pertussis toxin were 10 and $5 \mu \mathrm{g} / 100 \mu \mathrm{l}$, respectively, in $100 \mu \mathrm{l}$ of membrane suspension $(0.5$ to $0.7 \mathrm{mg}$ of protein). The mixtures were incubated for $1 \mathrm{~h}$ at $30^{\circ} \mathrm{C}$. The reaction was stopped with the additions of $50 \mu \mathrm{l}$ of ice-cold potassium phosphate, pH 7.5, and $150 \mu \mathrm{l}$ of a solution containing $0.125 \mathrm{M}$ Tris- $\mathrm{HCl}, \mathrm{pH} 6.8,4 \%$ SDS, $20 \%$ glycerol, $10 \%$ 2-mercaptoethanol, and $0.005 \%$ bromophenol blue. SDS-PAGE was carried out by a slight modification of the Laemmli method (21) on slab gels consisting of $10 \%$ separating gel and $4 \%$ stacking gel. To each well was added $100 \mu$ of the reaction mixture (2-3 $\mu \mathrm{Ci}$ of [ $\left.\left.{ }^{32} \mathrm{P}\right] \mathrm{NAD}\right)$. Autoradiograms were developed after $3 \mathrm{~d}$. Radioactivity in the appropriate band was counted by scintillation spectrometry. Membranes from 6and 24-mo-old rats were compared in each experiment and equal amounts of membrane protein were applied to the same slab gel.

Other assays. The production of cAMP by renal cells was determined as reported previously (22). Briefly, cAMP in perchloric acid extracts of the incubation reactions was diluted with 20-40 vol of sodium acetate buffer followed by acetylation and estimated with a commercial RIA kit (Incstar Corp., Stillwater, MN). Serum PTH level was determined with a PTH-MM RIA kit. Adenylate cyclase activity in renal cell membranes was measured as described (23). Protein was estimated by the Lowry method (24), with BSA as the protein standard. Serum $\mathrm{Ca}$ was determined by atomic absorption.

\section{Materials}

${ }^{45} \mathrm{Ca}(50 \mathrm{mCi} / \mathrm{ml})$ and $\left[{ }^{32} \mathrm{P}\right] \mathrm{NAD}(28.6 \mathrm{Ci} / \mathrm{mmol})$ were obtained from New England Nuclear (Boston, MA). bPTH (1-34), 6,800 U/mg, was from Pennisula Laboratories. Leupeptin was from Calbiochem-Behring Corp. (La Jolla, CA). PMFS, aprotinin, thymidine, and ATP were obtained from Sigma Chemical Co. (St. Louis, MO). GTP was from Pharmacia Fine Chemicals (Piscataway, NJ). NAD and DTT were from Boehringer-Mannheim Biochemicals (Indianapolis, IN). Cholera toxin and pertussis toxin were purchased from List Biological Laboratories (Campbell, CA).

\section{Results}

Effect of age of the rat on PTH-sensitive $\mathrm{Na}^{+}$-dependent $\mathrm{Ca}^{2+}$ efflux. Fig. 1 illustrates the effect of synthetic bPTH (1-34) on $\mathrm{Na}^{+}$-dependent ${ }^{45} \mathrm{Ca}^{2+}$ efflux from renal cells isolated from 6 -

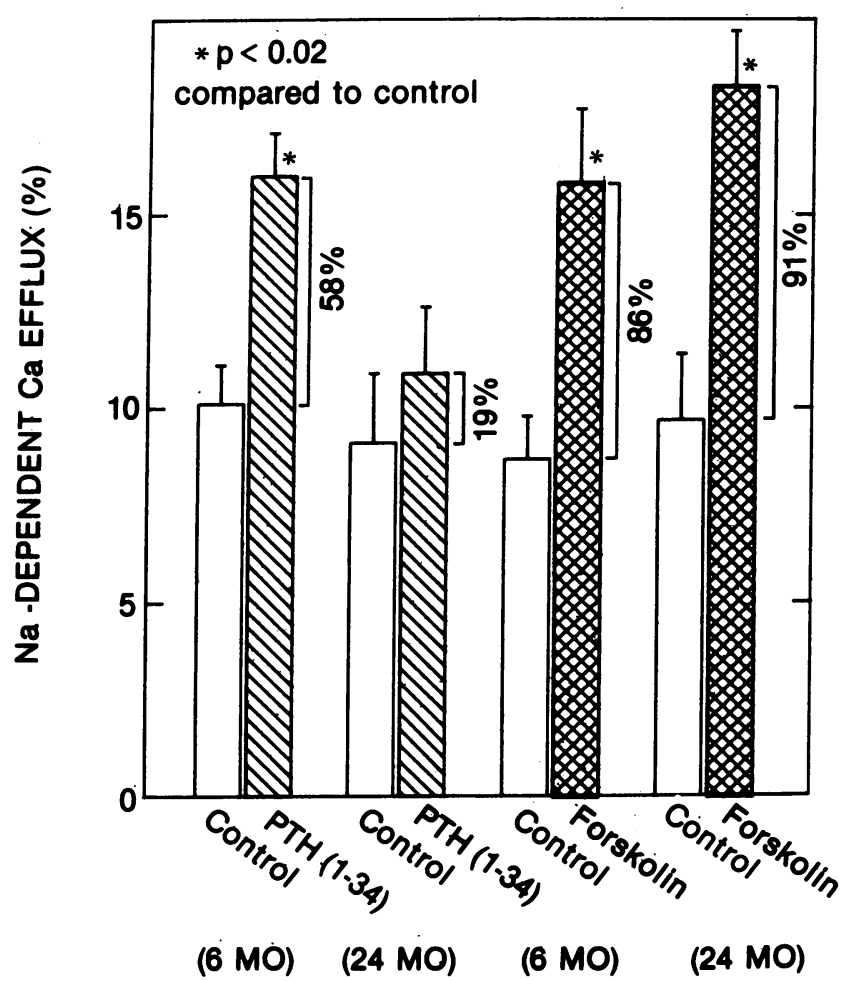

Figure 1. Effect of age of the rat on the sensitivity of $\mathrm{Na}^{+}$-dependent ${ }^{45} \mathrm{Ca}^{2+}$ efflux to PTH and forskolin. $\mathrm{Na}^{+}$-dependent ${ }^{45} \mathrm{Ca}^{2+}$ efflux was measured as described in the text. The values indicate the differences in efflux of ${ }^{45} \mathrm{Ca}^{2+}$ from cells incubated in an extracellular medium containing $140 \mathrm{mM} \mathrm{NaCl}$ or choline chloride. Each datum represents the mean $\pm \mathrm{SE}$ of five to six experiments, each triplicated. 
and 24-mo-old rats. The basal (vehicle control) $\mathrm{Na}^{+}$-dependent ${ }^{45} \mathrm{Ca}^{2+}$ efflux did not significantly differ in cells from the two age groups, being $10.1 \pm 1.2 \%$ and $9.1 \pm 1.8 \%$ in cells from 6- and 24-mo-old animals, respectively. When cells from adult $(6 \mathrm{mo})$ rats were preincubated for $1.5 \mathrm{~min}$ with $10 \mathrm{U} / \mathrm{ml}(3.4$ $\left.\times 10^{-7} \mathrm{M}\right) \mathrm{PTH}$, efflux was increased to $16.0 \pm 1.2 \%$, a $58 \%$ stimulation $(P<0.02)$. In contrast, when cells from senescent $(24 \mathrm{mo})$ rats were exposed to the hormone, stimulation of ${ }^{45} \mathrm{Ca}^{2+}$ efflux was markedly decreased, only $19 \%$ higher than basal. With cells from 6 -mo-old animals, ${ }^{45} \mathrm{Ca}^{2+}$ efflux into a choline-containing medium, in the absence of $\mathrm{Na}^{+}$, was not altered by PTH, $3.1 \pm 1.3 \%$ and $2.8 \pm 1.0 \%$ in control and hormone treated cells, respectively. These values were not significantly different from those obtained with cells from 24 mo animals (data not reported). Thus, the present findings indicated that the response of the $\mathrm{Na}^{+} / \mathrm{Ca}^{2+}$ exchange system to PTH in the senescent rat was blunted, confirming our earlier results (9).

Fig. 1 shows additionally that forskolin $(10 \mu \mathrm{M})$ enhanced $\mathrm{Na}^{+}$-dependent ${ }^{45} \mathrm{Ca}^{2+}$ efflux. But, in contrast to the response of the exchange system to PTH, stimulation by forskolin did not change in the aged rat. In cells from 6-mo-old rats, $\mathrm{Na}^{+}$dependent ${ }^{45} \mathrm{Ca}^{2+}$ efflux was increased $86 \%$ by forskolin, from $8.6 \pm 1.2 \%$ to $16.0 \pm 1.2 \%(P<0.02)$. In cells from 24 mo old rats the $\mathrm{Na}^{+}$-dependent efflux was enhanced $91 \%$, from 9.6 $\pm 1.5 \%$ to $18.3 \pm 1.4 \%(P<0.02)$. $\mathrm{Na}^{+}$-independent ${ }^{45} \mathrm{Ca}^{2+}$ efflux was not affected by forskolin in cells from adult and senescent animals (data not shown).

Effect of age of the rat on adenylate cyclase activity. The loss in the responsiveness of the $\mathrm{Na}^{+} / \mathrm{Ca}^{2+}$ exchange system to PTH with age was consistent with the finding that PTH-sensitive adenylate cyclase activity in membranes prepared from renal cells from senescent rats also declined. As shown in Table I, basal adenylate cyclase activity did not change significantly with age, being $67.3 \pm 5.2 \mathrm{pmol} \cdot 15 \mathrm{~min}^{-1} \cdot \mathrm{mg}^{-1}$ of protein and $60.0 \pm 10.7$ in membranes from 6- and 24-mo-old animals, respectively. In the presence of $10 \mathrm{U} / \mathrm{ml}$ of bPTH (1-34), cyclase activity increased 3.40 -fold with preparations from adult animals, but only 2.00 -fold with membranes from senescent rats. In the presence of a concentration of GTP $(1 \mu \mathrm{M})$; which by itself had little effect on basal activity, PTH increased adenyl-

Table I. Effect of PTH, Agonists, and Age on Adenylate Cyclase Activity in Renal Cell Membranes

\begin{tabular}{lccc}
\hline & \multicolumn{2}{c}{ Relative activity } & \\
\cline { 2 - 3 } \multicolumn{1}{c}{ Agonist } & $6 \mathrm{mo}$ & $24 \mathrm{mo}$ & \\
\hline Basal & 1.00 & 1.00 & \\
PTH & $3.40 \pm 0.15$ & $2.00 \pm 0.21$ & $P<0.01$ \\
GTP & $1.33 \pm 0.15$ & $1.54 \pm 0.20$ & NS \\
PTH + GTP & $6.80 \pm 0.82$ & $3.36 \pm 0.41$ & $P<0.01$ \\
GMP - PNP & $17.9 \pm 2.2$ & $11.4 \pm 1.9$ & $P<0.05$ \\
NaF & $22.0 \pm 1.7$ & $13.1 \pm 0.3$ & $P<0.01$ \\
Forskolin & $13.2 \pm 1.5$ & $9.9 \pm 1.3$ & NS \\
\hline
\end{tabular}

Basal activities in the membranes from 6- and 24-mo-old rats were $67.3 \pm 5.2$ and $60.0 \pm 10.7 \mathrm{pmol} \cdot 15 \mathrm{~min}^{-1} \cdot \mathrm{mg}^{-1}$ of protein, respectively. The values were given a relative activity of 1.00 . The concentrations used were: PTH, $10 \mathrm{U} / \mathrm{ml}\left(3.4 \times 10^{-7} \mathrm{M}\right)$; GTP, $1 \mu \mathrm{M}$; GMP - PNP, $10 \mu \mathrm{M}$; NaF, $7 \mathrm{mM}$; and forskolin, $10 \mu \mathrm{M}$.

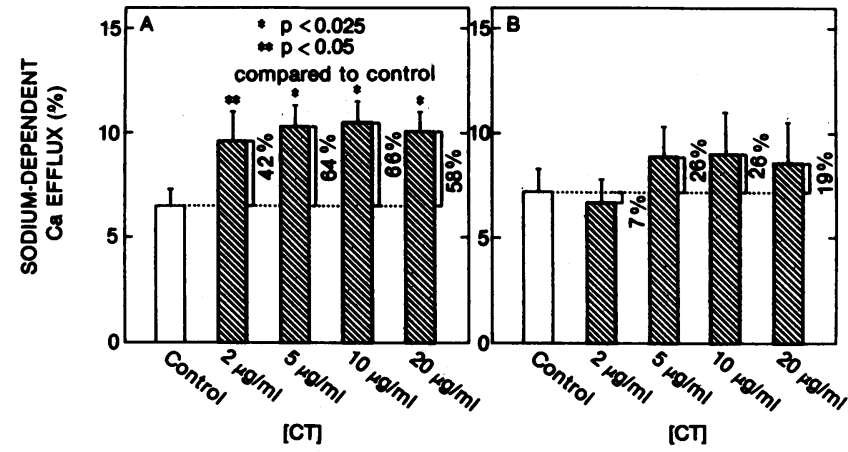

Figure 2. Effect of the concentration of cholera toxin (CT) on $\mathrm{Na}^{+}-$ dependent ${ }^{45} \mathrm{Ca}^{2+}$ efflux. In $A$, the cells were isolated from 6 mo rats; in $B$, the cells were isolated from 24-mo animals. Controls were carried out at each concentration of toxin. Other details of the experiment are described in the text and in Fig. 1. Each datum represents the mean $\pm \mathrm{SE}$ of five to six experiments, each triplicated.

ate cyclase activity 6.80- and 3.36-fold in membranes from 6and 24-mo-old animals, respectively. Comparable decreases with age in PTH-stimulated adenylate cyclase activity was found at all tested concentrations of PTH, ranging from 0.3 to $10 \mathrm{U} / \mathrm{ml}$ (data not shown). In addition, Table I shows that NaF-stimulated and GMP-PNP-stimulated adenylate cyclase activities were also decreased in membranes from aged rats. In contrast, forskolin-stimulated adenylate cyclase activity did not change significantly with age. At the concentration of forskolin $(10 \mu \mathrm{M})$ used in these experiments, the diterpine most likely increased adenylate cyclase activity by direct interaction with the catalytic component of the cyclase complex (25). On the other hand, the actions of NaF and GMP-PNP would be mediated by G-proteins (25), and the action of PTH could involve both hormone receptor and G-proteins. Since the responses to PTH, NaF, and GMP-PNP declined in preparations from senescent animals, whereas the responses to forskolin did not change with age, the possible involvement of G-proteins in the age-associated desensitization to PTH appeared to be an attractive hypothesis.

Responses of renal cells to cholera and pertussis toxins. Because cholera toxin should catalyze the ADP-ribosylation of $\mathrm{G}_{\mathrm{s}}$ resulting in increased adenylate cyclase activity, we examined how cells from the kidneys of 6- and 24-mo-old rats responded to the toxin. Fig. 2 shows the effects of different concentrations of cholera toxin on $\mathrm{Na}^{+}$-dependent ${ }^{45} \mathrm{Ca}^{2+}$ efflux. ${ }^{45} \mathrm{Ca}^{2+}$ efflux was enhanced with renal cells from adult animals (Fig. $2 \mathrm{~A}$ ). Compared to an efflux of $6.4 \pm 0.8 \%$ in control cells, $2,5,10$, and $20 \mu \mathrm{g} / \mathrm{ml}$ of cholera toxin increased ${ }^{45} \mathrm{Ca}^{2+}$ efflux to $9.1 \pm 1.4,10.5 \pm 1.3,10.6 \pm 0.9$, and $10.1 \pm 0.8 \%$, respectively, increases of $\sim 60 \%$ and comparable to that obtained with PTH (Fig. 1). With renal cells from senescent animals, the effect of cholera toxin on the $\mathrm{Na}^{+} / \mathrm{Ca}^{2+}$ exchange system was markedly diminished (Fig. $2 \mathrm{~B}$ ). No increase in ${ }^{45} \mathrm{Ca}^{2+}$ efflux was found with $2 \mu \mathrm{g} / \mathrm{ml}$ of the toxin and concentrations of toxin ranging from 5 to $20 \mu \mathrm{g} / \mathrm{ml}$ resulted in stimulations of $\sim 25 \%$, likewise comparable to that obtained with cells from aged animals incubated with PTH (Fig. 1). Consistent with these results were the findings that after the cells from 6 mo animals were preincubated with cholera toxin $(10 \mu \mathrm{g} / \mathrm{ml})$ the cAMP content of the cells plus medium (in the absence of a phosphodiesterase inhibitor) was increased $35 \%$, from $3.6 \pm 0.7$ $\mathrm{pmol} / \mathrm{mg}$ protein in the control to $4.7 \pm 0.6 \mathrm{pmol} / \mathrm{mg}$ protein in 

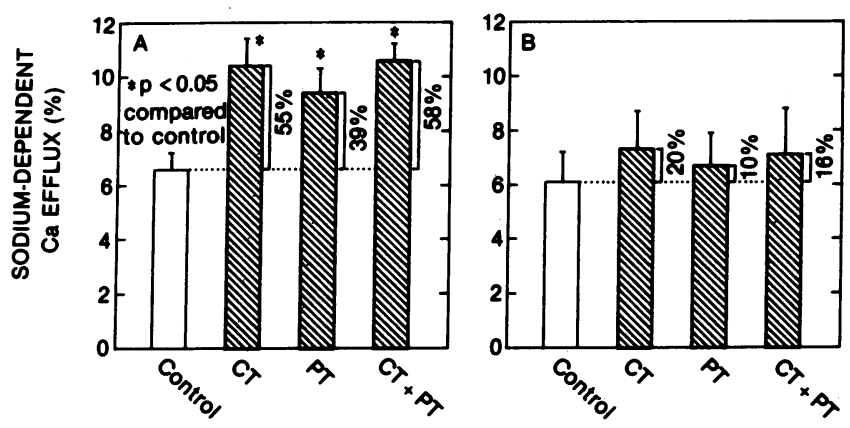

Figure 3. Effect of cholera $(C T)$ and pertussis $(P T)$ toxins on $\mathrm{Na}^{+}$dependent ${ }^{45} \mathrm{Ca}^{2+}$ efflux. In $A$, cells from 6 mo rats were used; in $B$, cells from 24 mo animals were used. The concentrations of cholera toxin and pertussis toxin were 10 and $1 \mu \mathrm{g} / \mathrm{ml}$, respectively. Other details of the experiment are described in the text and in Figs. 1 and 2. Each datum represents the mean $\pm \mathrm{SE}$ of 6-10 experiments, each triplicated.

toxin-treated cells $(P<0.01, n=6)$. The cAMP content did not significantly change when cholera toxin was preincubated with cells from 24 mo rats.

It might be predicted that treatment of renal cells with pertussis toxin would also increase adenylate cyclase activity (26), resulting in a stimulation of $\mathrm{Na}^{+} / \mathrm{Ca}^{2+}$ exchange. Fig. 3 compares the effect of pertussis toxin on cells from 6- and 24-mo-old animals. With cells from adult rats, pertussis toxin enhanced $\mathrm{Na}^{+}$-dependent ${ }^{45} \mathrm{Ca}^{2+}$ efflux about $40 \%$, from $6.7 \pm 0.6 \%$ to $9.3 \pm 0.7 \%(P<0.05)$ (Fig. $3 A)$. With cells from senescent animals, ${ }^{45} \mathrm{Ca}^{2+}$ efflux was not significantly increased, $6.1 \pm 1.0 \%$ and $6.7 \pm 1.2 \%$, with control and pertussis toxin-treated cells, respectively (Fig. $3 \mathrm{~B}$ ). Preincubation of pertussis toxin $(1 \mu \mathrm{g} / \mathrm{ml})$ with cells from adult animals increased the cAMP content (cells plus medium) by $28 \%$, from $3.2 \pm 0.6$ in the vehicle control to $4.1 \pm 0.6 \mathrm{pmol} / \mathrm{mg}$ protein in toxin-treated cells $(P<0.01, n=6)$. When cells from aged rats were used, the cAMP content was not altered. Fig. 3 also shows that treatment of cells with saturating concentrations of both cholera and pertussis toxins did not enhance $\mathrm{Na}^{+}$-dependent ${ }^{45} \mathrm{Ca}^{2+}$ efflux more than that found with cholera toxin alone. Moreover, the loss in response with age was still evident in the presence of both toxins.

$A D P$-ribosylation of $G$-proteins. Membranes prepared from renal cortical cells isolated from 6- and 24-mo-old rats were incubated with $\left[\alpha{ }^{32} \mathrm{P}\right] \mathrm{NAD}$ and either cholera or pertussis toxin to identify the $\alpha$ subunits of $G_{s}$ and $G_{i}$, respectively. Fig. 4 shows autoradiograms of the $\left[{ }^{32} \mathrm{P}\right] \mathrm{ADP}$ ribosylated proteins. With cholera toxin, two bands of $\sim 52$ and $45 \mathrm{kD}$ were found in membranes from adult animals corresponding to the previously described (17) two forms of $\mathrm{G}_{\mathrm{s}}-\alpha$. With pertussis toxin, a band of $\sim 41 \mathrm{kD}$ was seen, corresponding to the $\alpha$ subunit of $G_{i}$. With a mixture of two toxins, the three bands were clearly visible. None of the bands were seen when toxin was absent from the labeling medium. Fig. 4 also demonstrates that the intensities of the bands, representing the $\alpha$ subunits of both $G_{s}$ and $G_{i}$, were markedly decreased in membranes from aged rats.

The age-associated decreases in label were quantitated by cutting out the appropriate regions of the slab gels and counting for radioactivity. As shown in Fig. $5 A$, the 52 - and $45-\mathrm{kD} \alpha$ subunits of $\mathrm{G}_{\mathrm{s}}$ in membranes from senescent animals had only

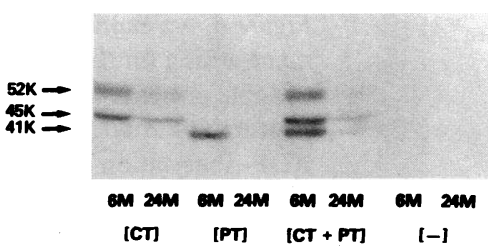

Figure 4. Autoradiograms of the ADP-ribosylated proteins formed after incubations of renal cell membranes from $6 \mathrm{mo}(6 M)$ and 24 mo $(24 M)$ rats with

cholera toxin $(C T)$, pertussis toxin $(P T)$, the combination of the two toxins, and in the absence of toxins. Description of the methods is given in the test. The same quantity of membrane protein was added to each lane. In different experiments the amount of protein ranged from 200 to $300 \mu \mathrm{g}$. The figure illustrates a typical gel pattern. Identical results were found with at least seven other membrane preparations from each age group.

$50 \pm 4$ and $56 \pm 4 \%$, respectively, the radioactivities found in membranes from adult animals. Radioactivity in the $41-\mathrm{kD}$ region, representing the $\alpha$ subunit of $G_{i}$, was decreased $24 \pm 2 \%$ in membranes from aged rats. Similar age-associated decreases in label were evident when the ADP-ribosylating medium contained both cholera and pertussis toxins (Fig. $5 \mathrm{~B}$ ). In membranes from 24-mo-old rats, the 52-, 45-, and 41-kD regions contained respectively, $50 \pm 7,54 \pm 6$, and $69 \pm 3 \%$ of the radioactivities measured in the corresponding regions of gels to which membranes from 6-mo-old rats were applied.

We tested the possibility that the greater ADP-ribosylation of G-proteins in membranes from 6-mo-old animals relative to membranes from 24-mo-old animals was due to the presence of a hypothetical activating factor in the membranes from the adult rat or the presence of a hypothetical inhibitory factor in the membranes from aged animals. Fig. 6 shows the results of experiments in which identical amounts of membrane protein from 6- and 24-mo-old animals were applied to gels and compared with the same amount of protein consisting of an equal mixture of membranes from 6- and 24-mo-old rats. Autoradiograms of the $52-$ and $45-\mathrm{kD}$ proteins ADP-ribosylated by cholera toxin and the $41-\mathrm{kD}$ protein ADP-ribosylated by pertussis toxin in the mixture of membranes from 6- and 24-mo rats were less intense than corresponding bands from 6-mo animals and more intense than corresponding bands from 24-mo animals (Fig. 6, top). Quantitation of the radioactivity (Fig. 6, bottom) revealed that for the 52-kD region, the relative


Figure 5. Quantitation of the age-associated decreases in ADP-ribosylated $\mathrm{G}_{\mathrm{s} \alpha}(45$ and $52 \mathrm{kD})$, catalyzed by cholera toxin $(C T)$, and $\mathrm{G}_{\mathrm{i}-\alpha}$ $(41 \mathrm{kD})$, catalyzed by pertussis toxin $(P T) . A$ shows the effects of the toxins acting separately, whereas $B$ illustrates the effects of cholera toxin and pertussis toxin in combination. Equal aliquots of the membrane suspensions from 6 and 24 mo rats were applied to the same gel. Each datum represents the mean \pm SE of seven gels, each with different membrane preparations. The amounts of label found associated with the proteins derived from 6 mo rats are given a relative value of $100 \%$. 


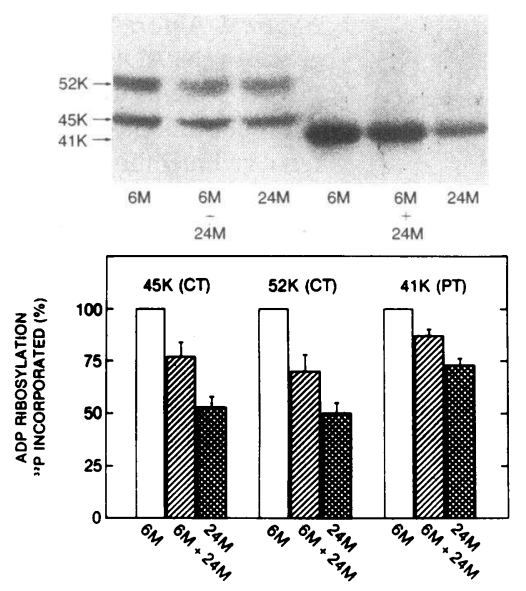

Figure 6. An experiment testing for the possible presence of activators or inhibitors of ADP-ribosylation in membranes from $6 \mathrm{mo}$ and 24 mo animals, respectively. Identical amounts of membrane protein from 6 and 24 mo animals were applied to gels and compared with the same amount of protein consisting of an equal mixture of membranes from 6 and 24 mo rats.

(Top) Shows radioautographs of a typical gel pattern. The three left lanes illustrate bands labeled by cholera toxin. The three right lanes illustrate bands labeled by pertussis toxin. (Bottom) The quantitation of the label associated with the bands. Each datum represents the mean $\pm \mathrm{SE}$ of five experiments. The radioactivity associated with the proteins isolated from $6 \mathrm{mo}$ animal is given a relative value of $100 \%$.

radioactivities were $100,70 \pm 3$, and $50 \pm 3 \%$ for membranes from 6-, 6 + 24-, and 24-mo rats, respectively; for the 45-kD region, the relative radioactivities were $100,77 \pm 5$, and $53 \pm 4 \%$ for membranes from 6-, $6+24-$, and 24-mo rats, respectively; and for the $41-\mathrm{kD}$ region, the relative radioactivities were 100 , $88 \pm 1$, and $72 \pm 1 \%$ for membranes from 6-, $6+24-$, and $24-\mathrm{mo}$ rats, respectively. These results showed that the radioactivities in the mixed membranes were midway between the counts found for the separate adult and aged membranes. Thus, these experiments provide no evidence for the presence of activating or inhibitory factors of toxin-mediated ADP-ribosylation in membranes from 6- or 24-mo-old rats.

Another possible cause for the more intense labeling of the G-proteins in membranes from 6-mo than from 24-mo-old animals was that in the intact membrane from senescent rats the $\alpha$ subunit was less accessible to the toxin for ADP-ribosylation. To test this possibility, the membranes were dispersed with $0.1 \%$ Lubrol PX for $1 \mathrm{~h}$ at room temperature and then incubated with $\left[\alpha-{ }^{32} \mathrm{P}\right] \mathrm{NAD}$ and pertussis toxin. Typical autoradiograms are shown in Fig. 7. Detergent dispersed membranes from 6-mo animals were more intensely labeled than were control membranes, perhaps suggesting the greater accessibility of ADP-ribosylation sites. However, Lubrol PX dispersed membranes from 24-mo rats still showed the marked decrease in label in the $\alpha$ band of $\mathrm{G}_{\mathrm{i}}$ relative to the band in the

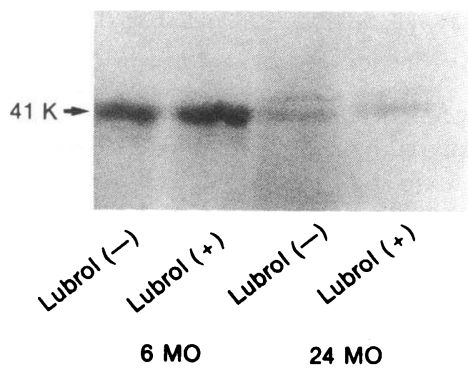

Figure 7. The effects of treating the membranes with the detergent Lubrol on pertussis toxin-catalyzed ADP-ribosylation. Equal membrane protein was applied to all lanes. The figure shows a typical experiment. Identical results were obtained in four experiments, each with different

membrane preparations, separate incubations with detergent and toxin, and electrophoresed on different gels. membranes from young animals. Thus, hindered accessibility of the $G_{i}$ protein to pertussis toxin and NAD could not account for the decreased ADP-ribosylation in membranes from senescent rats. To be noted in Fig. 7, was the doublet band at 40-41 kD seen in membranes from 24-mo animals. This doublet was found in many, but not all, autoradiograms of pertussis toxin catalyzed ADP-ribosylation of membranes.

Effect of parathyroidectomy (PTX) on the responses of the renal cell to $P T H$. The senescent rat presents with elevated levels of iPTH (10-13). In the rats used in this study, the serum iPTH concentrations in 6- and 24-mo-old animals were $100 \pm 4$ and $153 \pm 19 \mathrm{pmol} / \mathrm{liter}$, respectively $(P<0.01)$. Serum Ca concentrations did not differ with age, being $2.25 \pm 0.06$ and $2.24 \pm 0.04 \mathrm{mM}$ for 6 and 24 mo rats. Because of the higher levels of iPTH associated with the aged rat, we tested the hypothesis that the increased serum iPTH contributed to the desensitization to the hormone in the kidney. Therefore, 6and 24-mo rats were PTX or subjected to sham operations and the responses of the renal cells examined $48-72 \mathrm{~h}$ after surgery. In the 6-mo rat, iPTH concentration fell after PTX from $100 \pm 4$ to $76 \pm 4 \mathrm{pmol} / \mathrm{liter}(P<0.005)$. In the $24-\mathrm{mo}$ animal, iPTH concentration decreased from $153 \pm 19$ to $89 \pm 7 \mathrm{pmol} /$ liter $(P<0.01)$. The difference in the concentrations of iPTH in 6- and 24-mo animals after PTX was not statistically significant. Serum Ca concentrations was lowered similarly in both age groups, from $2.25 \pm 0.06$ to $1.61 \pm 0.02 \mathrm{mM}(P<0.001)$ in the adult and from $2.24 \pm 0.04$ to $1.56 \pm 0.03 \mathrm{mM}(P<0.001)$ in the senescent animal.

Fig. 8 illustrates the effects of PTX and the sham operation on renal cell $\mathrm{Na}^{+} / \mathrm{Ca}^{2+}$ exchange in 6- and 24-mo-old animals. With cells from sham-operated animals, $\mathrm{Na}^{+}$-dependent $\mathrm{Ca}^{2+}$ efflux in control cells were essentially the same for both ages, $10.1 \pm 1.1$ and $10.3 \pm 1.1 \%$ for 6 - and 24 -mo rats, respectively. In PTH-treated cells from 6- and $24-$ mo animals, ${ }^{45} \mathrm{Ca}^{2+}$ efflux were $15.9 \pm 1.0$ and $12.5 \pm 1.0 \%$, representing increases of 57 and $21 \%$ relative to the control. Thus, the age-related desensitization to PTH in this series of sham-operated animals was
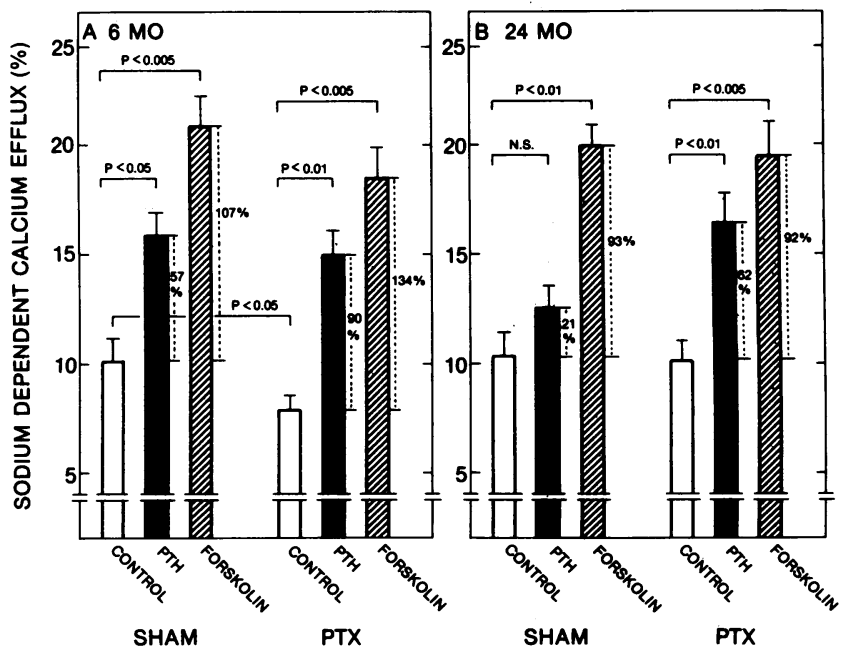

Figure 8. The effects of parathyroidectomy (PTX) of $(A)$ adult 6 mo rats and $(B)$ aged 24 mo animals on basal (control), PTH-, and forskolin-stimulated $\mathrm{Na}^{+}$-dependent ${ }^{45} \mathrm{Ca}^{2+}$ efflux. Details of the experiments are described in the text and in the legend of Fig. 1. Each datum represents the mean $\pm S E$ for six experiments, each carried out in triplicate. 

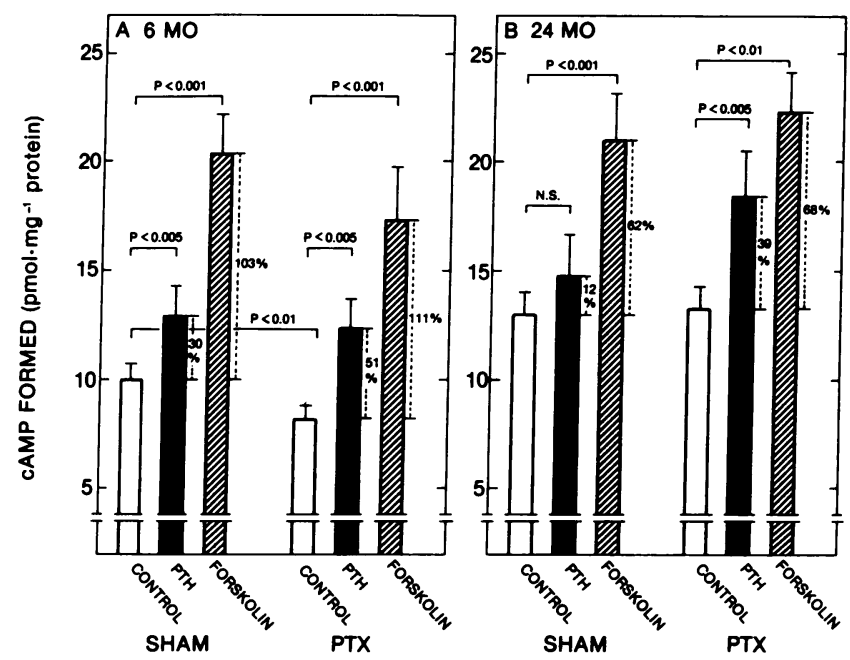

Figure 9. The effects of parathyroidectomy (PTX) of $(A) 6$ mo and (B) 24 mo rats on the cAMP produced by control cells and cells incubated with PTH and forskolin. Cells were incubated with PTH and forskolin for $1.5 \mathrm{~min}$, in the absence of a phosphodiesterase inhibitor. Other details of the experiment are described in the text. Each datum represents the mean \pm SE for six separate experiments, each carried out in duplicate.

identical to that found in the cohort of normal animals reported above (Fig. 1). $\mathrm{Na}^{+}$-dependent ${ }^{45} \mathrm{Ca}^{2+}$ efflux from cells from PTX 6 mo animals was decreased 21\% from the value found with cells from sham-operated rats, $10.1 \pm 1.1$ to $7.9 \pm 0.6 \%(P<0.05)$, a finding in agreement with that reported in our earlier study with very young $(2 \mathrm{mo})$ rats $(9)$. When the cells from PTX 6 mo animals were incubated in vitro with $3.4 \pm 10^{-7} \mathrm{M}$ PTH, $\mathrm{Na}^{+}$-dependent ${ }^{45} \mathrm{Ca}^{2+}$ efflux was increased to $15.0 \pm 1.1 \%$. With cells from aged animals, PTX did not alter the basal level of $\mathrm{Na}^{+}$-dependent ${ }^{45} \mathrm{Ca}^{2+}$ efflux. In vitro incubation of PTH with cells from the PTX 24 mo rats resulted in a $62 \%$ increase in the $\mathrm{Na}^{+}$-dependent ${ }^{45} \mathrm{Ca}^{2+}$ efflux, reaching a level of efflux, $16.4 \pm 1.3 \%$, comparable to the efflux found in cells from 6-mo-old animals. This result demonstrated that PTX of 24 mo rats completely reversed the decrease in PTHdependent $\mathrm{Na}^{+} / \mathrm{Ca}^{2+}$ exchange seen in the senescent animal. Fig. 8 shows additionally that PTX of 24 mo rats did not change the forskolin-dependent stimulation of $\mathrm{Na}^{+}$-dependent ${ }^{45} \mathrm{Ca}^{2+}$ efflux.

The blunting of PTH-dependent $\mathrm{Na}^{+} / \mathrm{Ca}^{2+}$ exchange in the aged rat and the negation of this decrease in the PTX senescent animal was in accord with results obtained in experiments in which production of PTH-dependent CAMP was measured. In these experiments, conducted in parallel to the transport assays, cells from 6 and 24 mo rats, sham-operated or PTX, were incubated for $1.5 \mathrm{~min}$ with $3.4 \times 10^{-7} \mathrm{PTH}$ or vehicle control (in the absence of a phosphodiesterase inhibitor). As shown in Fig. 9, with cells from 6 mo sham-operated animals the cAMP found in the cells and incubation medium increased by $30 \%$ after incubation with hormone, from $9.97 \pm 0.75$ to $12.8 \pm 1.24 \mathrm{pmol} / \mathrm{mg}$ protein $(P<0.01)$. With cells from $24 \mathrm{mo}$ sham-operated animals the cAMP found was increased only $12 \%$ by PTH, from $13.0 \pm 0.94$ to $14.8 \pm 1.86 \mathrm{pmol} / \mathrm{mg}$ protein, a difference that was not statistically significant. For reasons that remain unclear, it was noted that the control level of cAMP in cells from the senescent animal was higher than the control level in cells from the adult rat. With cells from $6 \mathrm{mo}$ PTX animals, cAMP in the control decreased relative to the sham-operated $(P<0.01)$. Incubation of cells from 6 mo PTX rats with PTH resulted in a $51 \%$ increase in cAMP formed, reaching the same level as found in hormone-treated cells of sham-operated $6 \mathrm{mo}$ animals. In contrast to the relative nonresponsiveness of 24 mo sham-operated animals to PTH, after the rats were PTX, cells from the aged rats were fully responsive to exogenous PTH; the cAMP found increased $39 \%$, from $13.27 \pm 0.86$ to $18.40 \pm 2.36 \mathrm{pmol} / \mathrm{mg}$ protein $(P$ $<0.005$ ). The response of the cells to forskolin was not significantly influenced by age nor by PTX (Fig. 9).

Measurements of adenylate cyclase activities in renal membranes provided additional evidence that the desensitization to PTH in senescent animals was reversed by PTX. Table II shows that the decreases in PTH-and PTH + GTP-stimulated adenylate cyclase found in membranes from sham-operated 24-mo-old rats relative to 6-mo-old rats were contradicted by PTX of the senescent animals. For example, the relative activities in membranes from sham-operated 6- and 24-moold rats incubated with PTH + GMP were $3.86 \pm 0.36$ and $2.10 \pm 0.26(P<0.005)$, but after PTX, although the relative activity in membranes from 6-mo-old rats did not change, being $3.66 \pm 0.18$, the relative activity in membranes from

Table II. Effect of PTX on Adenylate Cyclase Activity in Renal Cell Membranes

\begin{tabular}{|c|c|c|c|c|c|c|}
\hline \multirow[b]{3}{*}{ Agonist } & \multicolumn{5}{|c|}{ Relative activity } & \\
\hline & \multicolumn{2}{|c|}{ Sham } & & \multicolumn{2}{|c|}{ PTX } & \\
\hline & $6 \mathrm{mo}$ & $24 \mathrm{mo}$ & & $6 \mathrm{mo}$ & $24 \mathrm{mo}$ & \\
\hline Basal & 1.00 & 1.00 & & 1.00 & 1.00 & \\
\hline PTH & $2.79 \pm 0.23$ & $1.33 \pm 0.17$ & $P<0.005$ & $2.56 \pm 0.21$ & $1.92 \pm 0.21$ & NS \\
\hline GTP & $1.64 \pm 0.21$ & $1.54 \pm 0.10$ & NS & $1.46 \pm 0.16$ & $1.73 \pm 0.14$ & NS \\
\hline PTH + GTP & $3.86 \pm 0.36$ & $2.10 \pm 0.26$ & $P<0.005$ & $3.66 \pm 0.18$ & $3.55 \pm 0.30$ & NS \\
\hline GMP - PNP & $13.1 \pm 1.2$ & $8.91 \pm 0.41$ & $P<0.005$ & $12.6 \pm 1.42$ & $13.9 \pm 1.10$ & NS \\
\hline $\mathrm{NaF}$ & $20.4 \pm 1.2$ & $14.0 \pm 0.9$ & $P<0.005$ & $21.4 \pm 2.37$ & $17.1 \pm 0.88$ & NS \\
\hline
\end{tabular}

Basal activities in the membranes from sham-operated 6 and 24 mo animals were $67.3 \pm 5.2$ and $60.0 \pm 10.7 \mathrm{pmol} \cdot 15 \mathrm{~min}^{-1} \cdot \mathrm{mg}^{-1}$ of protein, respectively. In the membranes from PTX 6 and 24 mo rats the basal activities were $69.5 \pm 8.4$ and $57.2 \pm 7.5 \mathrm{pmol} \cdot 15 \mathrm{~min}^{-1} \cdot \mathrm{mg}^{-1}$ of protein. The values were given a relative activity of 1.00 . The concentrations of agonists are as reported in Table I. 

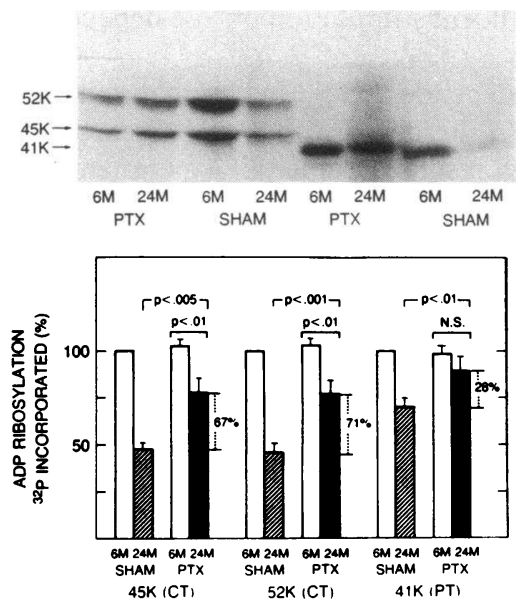

Figure 10. The effects of parathyroidectomy (PTX) of 6 and 24 mo rats on the ADP-ribosylation of Gs- $\alpha$ and Gi- $\alpha$ catalyzed by cholera toxin (CT) and pertussis toxin (PT), respectively. The top illustrates radio-autograms of a typical experiment. The same quantity of protein was applied to each lane. Similar results were obtained in 6 other experiments in which the membrane protein was varied from

300-500 $\mu \mathrm{g}$ in the different experiments. The bottom shows the quantitation of the label associated with the bands. Each datum is the mean \pm SE of 5-7 experiments. The radioactivities found in the bands from sham-treated 6 mo rats are given a relative value of $100 \%$.

24-mo rats increased to $3.55 \pm 0.30$, a value not different from that of the younger rat. Of additional importance, Table II shows that the decreases in NaF- and GMP-PNP-stimulated adenylate cyclase activities observed in 24 mo sham-operated rats were also negated when the animals were PTX.

The involvement of G-proteins in the reversal by PTX of the age-related desensitization to PTH was also suggested from experiments examining ADP-ribosylations of $G_{s}-\alpha$ and $G_{i}-\alpha$ (Fig. 10). Lanes 3 and 4, to which were applied equal aliquots of membrane protein from 6- and 24-mo rats, show the decreased label in cholera toxin-catalyzed ADP-ribosylation of the 52 and $45 \mathrm{kD} \alpha$ subunits of $\mathrm{G}_{\mathrm{s}}$ in the sham-operated aged animal. Lanes 1 and 2 show that, when equal aliquots of membrane protein from PTX animals were applied to the gel, the differences in label were no longer readily evident (Fig. 10, top). Counting the excised regions of the slab gels revealed that for the $52 \mathrm{kD}$ band, radioactivity was reduced by $\sim 50 \%$ in the membranes from sham-treated rats (Fig. 10, bottom). After PTX, ADP-ribosylation was increased $71 \%$ in the membranes from 24 mo rats, although full recovery was not attained in the 48-72 $\mathrm{h}$ period after surgery. PTX did not affect ADP-ribosylation of the $52 \mathrm{kD}$ protein derived from 6-mo animals. Similar responses were found for the $45 \mathrm{kD}$ subunit of $\mathrm{G}_{\mathrm{s}}-\alpha$. The label in $45 \mathrm{kD}$ decreased by $\sim 50 \%$ in the sham-operated 24 mo rat, and after PTX there was partial recovery. $\mathrm{G}_{\mathrm{i}}-\alpha$ also responded to PTX of the senescent animal. Autoradiograms of pertussis toxin-treated membranes show the decrease in label at $41 \mathrm{kD}$ in membranes from 24 mo sham-operated rats relative to 6 mo sham animals. This difference was largely negated when the animals were PTX (Fig. 10, top). Measurements of the radioactivity indicated that, with sham-operated animals, counts in the $41-\mathrm{kD}$ region were decreased by $\sim 30 \%$ in membranes from senescent animals relative to those in adult animals. After PTX, the counts in the $41-\mathrm{kD}$ region in membranes from 24 mo rats significantly increased and closely approached (not significantly different) the radioactivity found in membranes for PTX 6 mo rats (Fig. 10, bottom). Thus, for $\mathrm{G}_{\mathrm{i}}-\alpha$, PTX essentially completely blunted the age-related deficit in ADP-ribosylation.

\section{Discussion}

The present study showed that responses of renal cells to PTH, i.e., increased $\mathrm{Na}^{+} / \mathrm{Ca}^{2+}$ exchange, cAMP production and adenylate cyclase activity, were blunted in the senescent rat. Marcus and Gonzales (27) and Armbrecht et al. (28) found an age-related decline in PTH-dependent adenylate cyclase in renal cortical slices, but our results differed from theirs in that we found decrements from the mature adult to the aged rat, whereas they reported changes during development, from the immature 2-3 mo animal to the 12-13 mo adult. Moreover, we reported earlier that PTH-stimulated $\mathrm{Na}^{+} / \mathrm{Ca}^{2+}$ exchange in cells from maturing rats (2-12 mo of age) did not change (9). In addition, the present study demonstrated that $\mathrm{NaF}$ - and GMP-PNP-stimulated adenylate cyclase activities in renal membranes from 24 mo rats were decreased. Further, cholera toxin- and pertussis toxin-stimulated $\mathrm{Na}^{+}$-dependent ${ }^{45} \mathrm{Ca}^{2+}$ efflux and cAMP formation were also blunted in cells from senescent animals. Thus, in the aged rat, the finding of a broad pattern of refractoriness, in which responses to PTH and nonhormonal effectors were impaired, would suggest desensitization of the heterologous type (29). The desensitization with age to other hormone-receptor systems, i.e., $\beta$-adrenergic agonists and vasopressin, could not be tested because the adenylate cyclase activity of the isolated renal cortical cells responded negligibly, if at all, to these hormones (Liang, C. T., H. Hanai, L. Cheng, and B. Sacktor, unpublished observations.).

PTH-mediated refractoriness of the cAMP system was reported in a variety of experimental models, including prolonged (8-20 h) infusion of massive quantities of exogenous PTH (30-32), feeding animals a low Ca or vitamin D-deficient $\operatorname{diet}(15,33,34)$, and pre-treatment of cultured chick renal and bone cells with the hormone $(16,35)$. The general conclusion from these studies was that elevating circulating levels of PTH or increasing the concentration of the hormone in the medium down-regulated PTH-sensitive adenylate cyclase. In the aging rat model, serum levels of iPTH were increased (this study and 10-13). In the human, many studies indicated that serum levels of iPTH increased with age $(36,37)$. Moreover, it was recently demonstrated that the increased iPTH was biologically active and was not caused by retention of nonbiologically active PTH fragments by the aging kidney $(38,39)$. Thus, the bulk of evidence would support the proposal that the desensitization to PTH in the aging rat, as reported in the present study, represented an adaptive response to relatively prolonged stimulation by the hormone.

The attenuation of PTH-stimulated cAMP production in cultured chick bone cells after exposure of the cells to the hormone (35) and in renal membranes after infusion of parathyroid gland extract into dogs (31) was shown to be associated with loss of PTH receptors. Our preliminary studies with aging rats also indicated a decrease in maximum number of PTH agonist binding sites without change in binding affinity (40). Although in the senescent rat desensitization to PTH might be attributed, in part, to downregulation of PTH receptors, the present investigation clearly demonstrated that target cell resistance to PTH involved components of the adenylate cyclase complex distal to the receptor. Indeed, we showed that adenylate cyclase activity stimulated by NaF and GMP-PNP, agonists interacting with G-proteins and by-passing the receptor, was blunted in membranes from cells isolated from 24 mo rats. 
Moreover, the actions of cholera toxin and pertussis toxin in increasing $\mathrm{Na}^{+}$-dependent ${ }^{45} \mathrm{Ca}^{2+}$ efflux and in generating cAMP was also attenuated in cells from senescent animals. On the other hand, the actions of forskolin on these cellular responses did not decrease in cells from aged animals, suggesting that the catalytic component of the adenylate cyclase complex was probably not altered by age. Further, ADP-ribosylation of $\mathrm{G}_{\mathrm{s}}-\alpha$ and $\mathrm{G}_{\mathrm{i}}-\boldsymbol{\alpha}$ by the toxins showed decreased label in the $\mathrm{G}$-proteins from old animals. Thus, these results provided new evidence showing that decrements in G-protein activity was concomitant with the age-associated desensitization of renal cells to PTH. Alterations in the function of G-proteins were hypothesized in the heterologous desensitization to prostaglandin $E_{1}(41,42)$, chorionic gonadotropin (43), and glucagon (44) in various tissues. Modulation of the amounts, proportions, and/or properties of the G-proteins was also suggested to explain the changes in the catecholamine-stimulated adenylate cyclase system during the differentiation of preadipocytes into adipocytes (45).

It should be emphasized that this would not preclude the loss of PTH receptors as part of the mechanism of PTH-desensitization in aged rats. Indeed, our own experiments showing a decrement in PTH-binding sites in cells from 24 mo animals (40), would indicate age-dependent adaptations in both the PTH receptor and the G-proteins. Moreover, the present results would not rule out the possibility that the level or activity of cAMP-dependent protein kinase might also be altered as a function of age. In our study, only a maximal concentration of forskolin $(10 \mu \mathrm{M})$ was tested. Limiting concentrations of forskolin, resulting in less activation of cAMPdependent protein kinase, might have revealed decrements with age in processes distal to the generation of cAMP, in addition to sites proximal to the synthesis of the cyclic nucleotide.

The finding of decreased $\mathrm{G}_{\mathrm{s}}-\alpha$ protein in cells from 24-moold rats, as detected by ADP-ribosylation, was consistent with the blunting of the stimulation of adenylate cyclase by PTH, $\mathrm{NaF}$, and GMP-PNP in the aged animal. Similar decrements of $\sim 50 \%$ were found for both the 52- and $45-\mathrm{kD}$ forms of $\mathrm{G}_{\mathrm{s}}-\alpha$. The two forms of $\mathrm{G}_{\mathrm{s}}-\alpha$ were reported to arise from distinct species of mRNA (46-48). In turn, these long and short forms of $G_{s}-\alpha$ mRNA were products of alternative splicing of the $G_{s}-\alpha$ gene $(46,47)$. Whether the changes in normal functional $G_{s}-\alpha$ proteins in senescence reflected the steady-state levels of the mRNAs, the stability of the mRNAs, their translation, and/or the transcription of the $G_{s}-\alpha$ gene awaits further investigation. It is of interest that target organ resistance to PTH is characteristic of the genetic disorder, pseudohypoparathyroidism type Ia (49). Moreover, the genetic lesion for the blunting of the response to PTH, and other hormones (50), was recently shown to affect the maintenance of $\mathrm{mRNA}$ levels for the multiple forms of the $\mathrm{G}_{\mathrm{s}}-\alpha$ subunit (51). Other possible alternative explanations for the age-associated decreases in ADP-ribosylation of $\mathrm{G}_{\mathrm{s}}-\alpha$ and $\mathrm{G}_{\mathrm{i}}-\alpha$ might include decrements in a protein cofactor required for ADP-ribosylation of $\mathrm{G}_{\mathrm{s}}-\alpha$ by cholera toxin (52-55), and alterations in the $\beta-\gamma$ subunit that modulates ADP-ribosylation of $\mathrm{G}_{\mathrm{i}}-\alpha$ by pertussis toxin (56). Future studies are necessary to test these hypotheses.

A major finding reported in the present study was that the age-associated blunting of the responses of renal cells to PTH were completely or mostly reversed by surgical removal of the parathyroid gland from the senescent rat. This was evident from the observations that the decreased $\mathrm{Na}^{+} / \mathrm{Ca}^{2+}$ exchange activity (Fig. 8), cAMP formation (Fig. 9), and membranal adenylate cyclase activity (Table II) in cells from 24-mo-old rats could be restored to the levels found in 6-mo-old rats by PTX of the aged animals. Moreover, the decreased label in cholera toxin-catalyzed ADP-ribosylated $\mathrm{G}_{\mathrm{s}}-\alpha$ and pertussis toxin-catalyzed ADP-ribosylated $G_{i-\alpha} \alpha$ found in cells from 24-mo-old rats was also largely negated by the surgery. Since the aged rat had elevated concentrations of serum iPTH and this prolonged hormonal stimulation during aging likely led to adaptive responses resulting in desensitization, it might be reasonable to propose that removal of the stimulus, by ablation of the gland, would restore sensitivity. The increased ADP-ribosylation of $\mathrm{G}_{\mathrm{s}}-\alpha$ and $\mathrm{G}_{\mathrm{i}}-\alpha$ after PTX indicated that G-proteins were involved in this reversal. Our preliminary observations, reported elsewhere (40), revealed an increase in PTH receptor binding sites in cells from aged rats subjected to PTX. Thus, after PTX, alterations in both G-proteins and PTH receptors appeared to contribute to recovery of sensitivity.

The mechanisms by which the serum concentration of iPTH was increased in the aged rat are not clear. Secondary hyperparathyroidism has been a universal finding in patients and experimental animals with chronic renal insufficiency (57). The aged rats used in the present study did exhibit various degrees of chronic renal failure and reduced glomerular filtration rates (13). Thus, the reduced functional renal mass in the aged rat could contribute, in part, to the elevated serum hormone concentration. Indeed, it was hypothesized that the etiology of senile osteoporosis was secondary hyperparathyroidism due to renal failure (58). However, recent studies in women correlating serum levels of biologically active PTH and urinary cAMP/glomerular filtration rate indicated that decreases in renal function were not the major factor accounting for the rise in serum iPTH with age $(38,59)$. In addition, the senescent rat was found to be hypophosphatemic (13), whereas typically the retention of phosphorous would be a significant contributory factor in the development of secondary hyperparathyroidism in renal insufficiency (57). Moreover, steadystate concentrations of serum total calcium (13) and ionized calcium (Takamoto, S., L. Cheng, C. T. Liang, H. Hanai, and B. Sacktor, unpublished observations) were not measurably decreased in the 24-mo rat. An alternative explanation for the increase in PTH with age might stem from findings that altered vitamin D metabolism could modulate iPTH levels. It was reported that parathyroid cells exposed to 1,25-dihydroxycholecalciferol had a significantly decreased rate of PTH secretion due to declines in the steady state level of prepro-PTH mRNA and the rate of PTH gene transcription (60-62). Decreased suppression would be consistent with previous findings of a lower concentration of the vitamin $\mathrm{D}$ metabolite in aged rats (63) and a decreased renal 1- $\alpha$ hydroxylase activity in mitochondria from the 24 mo animal (64). Another possible explanation for the hyperparathyroidemia in the senescent rat could be an age-associated alteration in the set-point for $\mathrm{Ca}^{2+}$-regulated PTH release. Indeed, a recent study provided suggestive evidence that the decrease in iPTH secretion in response to an elevation in $\mathrm{Ca}^{2+}$ in glands from old rats was smaller than that observed in glands from young animals (65). Whether these or other mechanisms are responsible for the increase in iPTH in the aged rat will require further experimentation. Neverthe- 
less, the present results suggest that the age-associated blunting in the responses of renal cells to PTH was due, at least in part, to an alteration in G-protein function and that this deficit could be reversed by removal of the parathyroid gland.

\section{References}

1. Sutton, R. A. L., and J. H. Dirks. 1981. Calcium and magnesium: renal handling and disorders of metabolism. In The Kidney. B. M. Brenner and F. C. Rector, Jr., editors. W. B. Saunders Co., Philadelphia. 1:551-618.

2. Kurokawa, K. 1985. Cellular mechanisms and sites of hormone action in the kidney. In The Kidney: Physiology and Pathophysiology. D. W. Seldin and G. Giebisch, editors. Raven Press, New York. 1:739-774.

3. Aurbach, G. D., R. Marcus, J. Heersche, S. Marx, H. Niall, G. W. Treagor, H. T. Keutmann, and J. T. Potts, Jr. 1971. Hormones and other factors regulating calcium metabolism. Ann. NY Acad. Sci. 185:386-394.

4. Scoble, J. E., D. Moskowitz, and K. A. Hruska. 1986. Dibutyryladenosine 3',5'-cyclic monophosphate (dBcAMP) does not mimic the action of parathyroid hormone (PTH) on canine proximal tubular basolateral membrane $\mathrm{Na}^{+}: \mathrm{Ca}^{2+}$. Adv. Exp. Med. Biol. 208:537-541.

5. Gmaj, P., H. Murer, and R. Kinne. 1979. Calcium ion transport across plasma membranes isolated from rat kidney. Biochem. $J$. 178:549-557.

6. Jayakumar, A., L. Cheng, C. T. Liang, and B. Sacktor. 1984. Sodium gradient-dependent calcium uptake in renal basolateral membrane vesicles. J. Biol. Chem. 259:10827-10833.

7. van Heeswijk, M. P. E., J. A. M. Geertsen, and C. H. van Os. 1984. Kinetic properties of the ATP-dependent $\mathrm{Ca}^{2+}$ pump and the $\mathrm{Na}^{+} / \mathrm{Ca}^{2+}$ exchange system in basolateral membranes from rat kidney cortex. J. Membr. Biol. 79:19-31.

8. Scoble, J. E., S. Mills, and K. A. Hruska. 1985. Calcium transport in canine renal basolateral membrane vesicles. J. Clin. Invest. 75:1096-1105.

9. Hanai, H., M. Ishida, C. T. Liang, and B. Sacktor. 1986. Parathyroid hormone increases sodium/calcium exchange activity in renal cells and the blunting of the response in aging. J. Biol. Chem. 261:5419-5425.

10. Armbrecht, H. J., L. R. Forte, and B. P. Halloran. 1984. Effect of age and dietary calcium on renal $25(\mathrm{OH}) \mathrm{D}$ metabolism, serum 1,25(OH $)_{2}$ D, and PTH. Am. J. Physiol. 246:E266-E270.

11. Kalu, D. N., R. H. Hardin, R. Cockerham, and B. P. Yu. 1983. Aging and dietary modulation of rat skeleton and parathyroid hormone. Endocrinology. 115:1239-1247.

12. Fujita, T., M. Ohata, K. Ota, T. Tsuda, A. Uezu, K. Okano, and M. Yoshikawa. 1976. Aging and parathyroid hormone secretion. $J$. Gerontol. 31:523-526.

13. Kiebzak, G. M., and B. Sacktor. 1986. Effect of age on renal conservation of phosphate in the rat. Am. J. Physiol. 251:F399-F407.

14. Chao, W.-T. H., and L. R. Forte. 1982. Rat kidney cells in primary culture: hormone-mediated desensitization of the adenosine $3^{\prime}, 5^{\prime}$-monophosphate response to parathyroid hormone and calcitonin. Endocrinology. 111:252-259.

15. Forte, L. R., S. G. Langeluttig, R. E. Poelling, and M. L. Thomas. 1982. Renal parathyroid hormone receptors in the chick: downregulation in secondary hyperparathyroid animal models. Am. J. Physiol. 242:E154-E163.

16. Henry, H. L., N. S. Cunningham, and T. A. Noland, Jr. 1983. Homologous desensitization of cultured chick kidney cells to parathyroid hormone. Endocrinology. 113:1942-1948.

17. Gilman, A. G. 1984. G proteins and dual control of adenylate cyclase. Cell. 36:577-579.

18. Sternweis, P. C., and J. D. Robishaw. 1984. Isolation of two proteins with high affinity for guanine nucleotides from membranes of bovine brain. J. Biol. Chem. 259:13806-13813.
19. Ui, M. 1984. Islet-activating protein, pertussis toxin: a probe for functions of the inhibitory guanine nucleotide regulatory component of adenylate cyclase. Trends Pharmacol. Sci. 5:277-279.

20. Sacktor, B., N. Lepor, and E. G. Schneider. 1981. Stimulation of the efflux of L-glutamate from renal brush-border membrane vesicles by extravesicular potassium. Bioscience Rep. 1:709-713.

21. Laemmli, V. K. 1970. Cleavage of structural proteins during the assembly of the head of bacteriophage T4. Nature (Lond.). 227:680-685.

22. Cheng, L., C. T. Liang, and B. Sacktor. 1981. In vitro effects of parathyroid hormone on kidney cortical slices: cAMP responses and concomitant inhibition of the $\mathrm{Na}^{+}$gradient-dependent uptake of phosphate by brush border membrane vesicles isolated from the renal slices. Endocrinol. Res. Commun. 8(2):97-110.

23. Liang, C. T., and B. Sacktor. 1977. Preparation of renal cortex basal-lateral and brush border membranes. Biochim. Biophys. Acta. 466:474-487.

24. Lowry, O. H., N. J. Rosebrough, A. L. Farr, and R. J. Randall. 1951. Protein measurement with the Folin phenol reagent. J. Biol. Chem. 193:265-275.

25. Birnbaumer, L., J. Codina, R. Mattera, R. A. Cerione, J. D. Hildebrandt, T. Sunyer, F. J. Rojas, M. G. Caron, R. J. Lefkowitz, and R. Iyengar. 1985. Regulation of hormone receptors and adenylyl cyclases by guanine nucleotide binding N proteins. Recent Prog. Hormone Res. 41:41-99.

26. Katada, T., T. Amano, and M. Ui. 1982. Modulation by isletactivating protein of adenylate cyclase activity in C6 glioma cells. $J$. Biol. Chem. 257:3739-3746.

27. Marcus, R., and D. Gonzales. 1982. Age-related change in parathyroid hormone-dependent cyclic AMP formation in rat kidney. Mechanism Ageing Devel. 20:353-360.

28. Armbrecht, H. J., M. A. Boltz, and L. R. Forte. 1986. Effect of age on parathyroid hormone and forskolin stimulated adenylate cyclase and protein kinase activity in the renal cortex. Exp. Gerontol. 21:512-522.

29. Sibley, D. R., and R. L. Lefkowitz. 1985. Molecular mechanisms of receptor desensitization using the $\beta$-adrenergic receptor-coupled adenylate cyclase system as a model. Nature (Lond.). 317:124129.

30. Nickols, G. A., D. L. Carnes, C. S. Anast, and L. R. Forte. 1978. Parathyroid hormone-mediated refractoriness of rat kidney cyclic AMP system. Am. J. Physiol. 236:E401-E409.

31. Mahoney, C. A., and R. A. Nissenson. 1983. Canine renal receptors for parathyroid hormone. J. Clin. Invest. 72:411-421.

32. Tamayo, J., E. Bellorin-Font, G. Sicard, D. Anderson, and D. J. Martin. 1982. Desensitization to parathyroid hormone in the isolated perfused canine kidney: reversal of altered receptor-adenylate cyclase system by guanosine triphosphate in vitro. Endocrinology. 111:13111317.

33. Carnes, D. D., C. S. Anast, and L. R. Forte. 1973. Impaired renal adenylate cyclase response to parathyroid hormone in the calcium-deficient rat. Endocrinology. 102:45-51.

34. Tamayo, J., E. Bellorin-Fort, and K. J. Martin. 1983. Effects of dietary-induced hyperparathyroidism on the parathyroid hormone-receptor-adenylate cyclase system of canine kidney. J. Clin. Invest. 72:422-432.

35. Teitelbaum, A. P., C. M. Silve, K. O. Nyiredy, and C. D. Arnaud. 1986. Down-regulation of parathyroid hormone (PTH) receptors in cultured bone cells is associated with agonist-specific intracellular processing of PTH-receptor complexes. Endocrinology. 118:595-602.

36. Riggs, B. L., C. D. Arnaud, J. Jowsey, R. S. Goldsmith, and P. J. Kelly. 1973. Parathyroid function in primary osteoporosis. J. Clin. Invest. 52:181-184.

37. Wiske, P. S., S. Epstein, N. H. Bell, S. F. Queener, J. Edmondson, and C. C. Johnston. 1979. Increases in immunoreactive parathyroid hormone with age. $N$. Engl. J. Med. 300:1419-1421. 
38. Forero, M. S., R. F. Klein, R. A. Nissenson, K. Nelson, H. Heath III, C. D. Arnaud, and B. L. Riggs. 1987. Effect of age on circulating immunoreactive and bioactive parathyroid hormone levels in women. J. Bone Miner. Res. 2:363-366.

39. Young, G., R. Marcus, J. R. Minkoff, L. Y. Kim, and G. V. Segre. 1987. Age-related rise in parathyroid hormone in man: the use of intact and midmolecule antisera to distinguish hormone secretion from retention. J. Bone Miner. Res. 2:367-374.

40. Sacktor, B., H. Hanai, M. Goldman, L. Cheng, and M. Chorev. 1987. Desensitization to PTH in the aged rat is associated with a decreased number of receptors: partial reversal after parathyroidectomy (PTX). The American Society of Nephrology 20th Annual Meeting, Washington, DC. 201A. (Abstr.)

41. Kassis, S., and P. H. Fishman. 1982. Different mechanisms of desensitization of adenylate cyclase by isoproterenol and prostaglandin $\mathrm{E}_{1}$ in human fibroblasts. J. Biol. Chem. 257:5312-5318.

42. Garrity, M. J., T. J. Andreasen, D. R. Storm, and R. P. Robertson. 1983. Prostaglandin E-induced heterologous desensitization of hepatic adenylate cyclase. J. Biol. Chem. 258:8692-8697.

43. Kirchick, H. J., R. Iyengar, and L. Birnbaumer. 1983. Human chorionic gonadotropin-induced heterologous desensitization of adenylyl cyclase from highly luteinized rat ovaries: attenuation of regulatory N component activity. Endocrinology. 113:1638-1646.

44. Rich, K. A.; J. Codina, G. Floyd, R. Sekura, J. D. Hildebrandt, and R. Iyengar. 1984. Glucagon-induced heterologous desensitization of the MDCK cell adenylyl cyclase. J. Biol. Chem. 259:7893-7901.

45. Lai, E., O. M. Rosen, and C. S. Rubin. 1981. Differentiationdependent expression of catecholamine-stimulated adenylate cyclase. J. Biol. Chem. 256:12866-12874.

46. Robishaw, J. D., M. D. Smigel, and A. G. Gilman. 1986 Molecular basis for two forms of the $G$ protein that stimulates adenylate cyclase. J. Biol. Chem. 261:9587-9590.

47. Bray, P., A. Carter, C. Simons, V. Guo, C. Puckett, J. Kamholz, A. Spiegel, and M. Nirenbert. 1986. Human cDNA clones for four species of $\mathrm{G}_{\alpha_{\mathrm{s}}}$ signal transduction protein. Proc. Natl. Acad. Sci. USA. 83:8893-8897.

48. Mattera, R., J. Codina, A. Crozat, V. Kidd, S. L. C. Woo, and L. Birnbaumer. 1986. Identification by molecular cloning of two forms of the $\alpha$-subunit of the human liver stimulatory $\left(\mathrm{G}_{\mathrm{s}}\right)$ regulatory component of adenylyl cyclase. FEBS (Fed. Eur. Biochem. Soc.) Lett. 206:36-42.

49. Chase, L. R., G. L. Melson, and G. D. Aurbach. 1969. Pseudohypoparathyroidism: defective excretion of $3^{\prime}, 5^{\prime}$-AMP in response to parathyroid hormone. J. Clin. Invest. 48:1832-1844.

50. Spiegel, A. M., M. A. Levine, R. W. Aurbach, R. W. Downs, Jr., S. J. Marx, R. D. Lasker, A. M. Moses, and N. A. Breslau. 1982. Deficiency of hormone receptor-adenylate cyclase coupling protein: basis for hormone resistance in pseudohypoparathyroidism. Am. J. Physiol. 243:E37-E42.

51. Carter, A., C. Bardin, R. Collins, C. Simons, P. Bray, and A. Spiegel. 1987. Reduced expression of multiple forms of the $\alpha$ subunit of the stimulatory GTP-binding protein in pseudohypoparathyroidism type Ia. Proc. Natl. Acad. Sci. USA. 84:7266-7269.

52. Enomoto, K., and D. M. Gill. 1980. Cholera toxin activation of adenylate cyclase. J. Biol. Chem. 255:1252-1258.

53. Schleifer, L. S., R. A. Kahn, E. Hanski, J. K. Northup, P. C. Sternweis, and A. G. Gilman. 1982. Requirements for cholera toxindependent ADP-ribosylation of the purified regulatory component of adenylate cyclase. J. Biol. Chem. 257:20-23.

54. Kahn, R. A., and A. G. Gilman. 1986. The protein cofactor necessary for ADP-ribosylation of $\mathrm{G}_{\mathrm{s}}$ by cholera toxin is itself a GTP binding protein. J. Biol. Chem. 261:7906-7911.

55. Tsai, S.-C., M. Noda, R. Adamik, P. P. Chang, H.-C. Chen, J. Moss, and M. Vaughan. 1988. Stimulation of choleragen enzymatic activities by GTP and two soluble proteins purified from bovine brain. J. Biol. Chem. 263:1768-1771.

56. Katada, T., M. Oinuma, and M. Ui. 1986. Two guanine nucleotide-binding proteins in rat brain serving as the specific substrate of islet-activating protein, pertussis toxin. J. Biol. Chem. 261:8182-8191.

57. Slatopolsky, E., K. J. Martin, J. J. Morrissey, and K. A. Hruska. 1984. Parathyroid hormone: alterations in chronic renal failure. Proceedings of the IXth International Congress of Nephrology, Los Angeles, CA. 1292-1304.

58. Berlyne, G. M., J. Ben-Ari, A. Kushelevski, A. Idelman, D. Galinsky, M. Hirsch, R. Shainkin, R. Yageil, and M. Zlotnik. 1975. The aetiology of senile osteoporosis: secondary hyperparathyroidism due to renal failure. Quart. J. Med. 175:505-521.

59. Gallagher, J. C., B. L. Riggs, C. M. Jerpbak, and C. D. Arnaud. 1980. The effect of age on serum immunoreactive parathyroid hormone in normal and osteoporotic women. J. Lab. Clin. Med. 95:373385.

60. Silver, J., J. Russell, and L. M. Sherwood. 1985. Regulation by vitamin D metabolites of messenger ribonucleic acid for preproparathyroid hormone in isolated bovine parathyroid cells. Proc. Natl. Acad. Sci. USA. 82:4270-4273.

61. Russell, J., D. Lettieri, and L. M. Sherwood. 1986. Suppression by $1,25(\mathrm{OH})_{2} \mathrm{D}_{3}$ of transcription of the pre-proparathyroid hormone gene. Endocrinology. 119:2864-2866.

62. Chan, Y., C. McKay, E. Dye, and E. Slatopolsky. 1986. The effect of 1,25 dihydroxycholecalciferol on parathyroid hormone secretion by monolayer cultures of bovine parathyroid cells. Calcif. Tissue Int. 38:27-32.

63. Gray, R. W. 1981. Effects of age and sex on the regulation of plasma $1,25-(\mathrm{OH}) 2-\mathrm{D}$ by phosphorus in the rat. Calcif. Tissue Int. 33:477.

64. Ishida, M., B. Bulos, S. Takamoto, and B. Sacktor. 1987. Hydroxylation of 25-hydroxyvitamin $\mathrm{D}_{3}$ by renal mitochondria from rats of different ages. Endocrinology. 121:443-448.

65. Wongsurawat, A., and H. J. Armbrecht. 1987. Comparison of calcium effect on in vitro calcitonin and parathyroid hormone release by young and aged thyroparathyroid glands. Exp. Gerontol. 22:263269. 